\title{
山形騾新山産石英租面岩質斑岩中の 斑狀長石の對稱
}

理學博士 渡 連 新 六

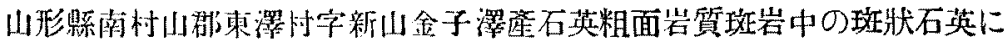

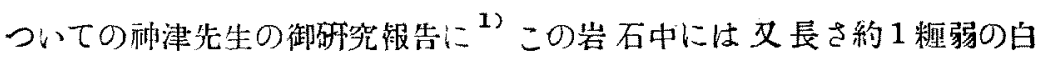
色乃至黃白色の長石が玟晶として多数存在することが記されてねる。神津 先生及び其の協同研究者の研究に依ると, 之は㱠んど純桲のアルバイトを 見るべきものであるが，ての光學尛から兄ると，かなり單科晶系に近いる

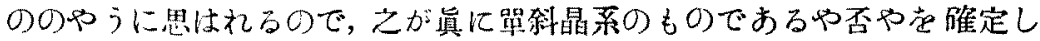

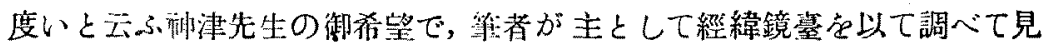
た。十分なる結果は得られなかつたが，こ、にその概姴を報告する。

\begin{tabular}{|c|c|c|c|c|}
\hline No. & 溥片方向 & 雙 晶 軸 & 成分 $(\% A n)$ & 其 \\
\hline 1 & $\mathscr{Z}(010)$ & $\ldots \ldots$ & 0 & $2 \nabla=72^{2}(+)$ \\
\hline 2 & $\mathscr{H}(001)$ & $1(010)$ & 3 & ...... \\
\hline 3 & $\mathscr{Z}(001)$ & $\perp(010)$ & 5 & $\cdots \cdots$ \\
\hline 4 & $\mathscr{Z}(001)$ & $\frac{1}{\|(010)}$ & $o$ & $\ldots \ldots$ \\
\hline
\end{tabular}

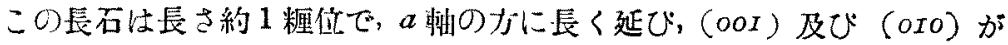

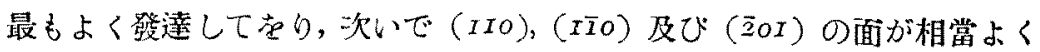

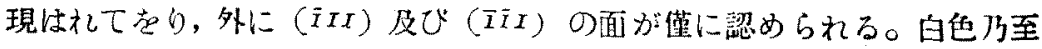
㣴白色，不透明で，母岩の分解したものから比較的容易に分雛することが

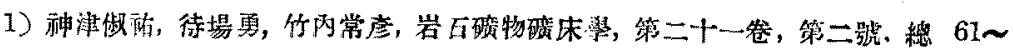
65. 昭 14. 
出來る。晶系の决定の䉆めに面角の測定を試みたが，面の反射が良好でな く，测定困難で中止した。

神津先生等が酦に $(O O I)$ 及び $(O I O)$ に本行な薄片數枚を作製せられて

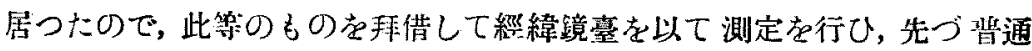
の斜長石の成分決定の 場合と同樣に，測定せられた北學方位から，双晶軸

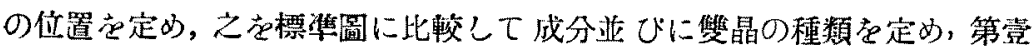
表の樣な結果が得られた。No.1のものには雙鼠が見られなかつたので, 艺 軸角の大きさから成分克推定した。

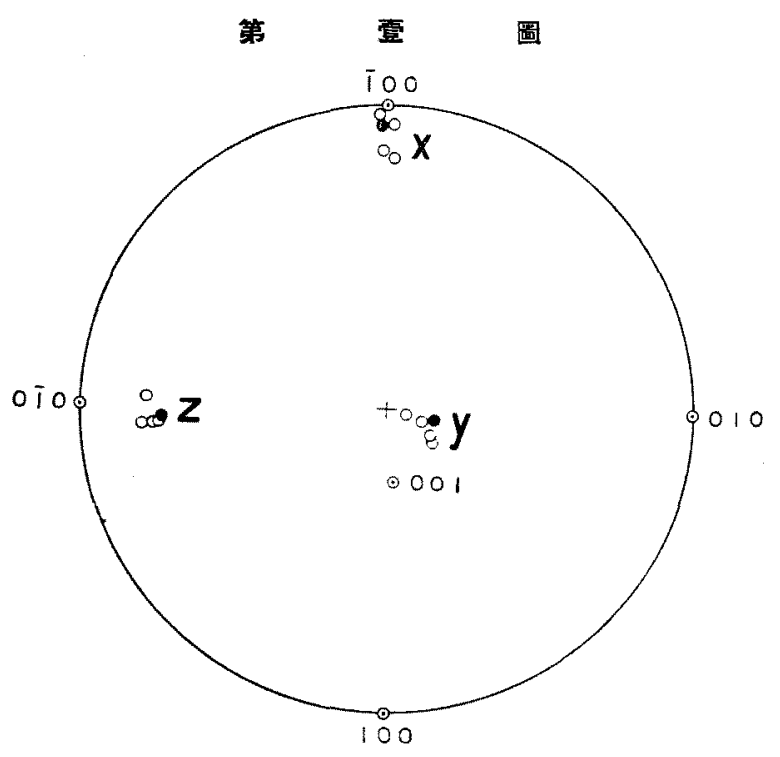

以上は既にこの長石が㫮通の三科晶系のものと同樣である事を前提とし

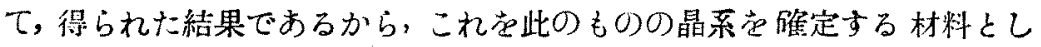
て使用することは適當でないが，今假りにこ、に求められた稚晶軸の位置 が正しく, 及薄片の方向も正しく作られて学るものとし, 測定に依つて得

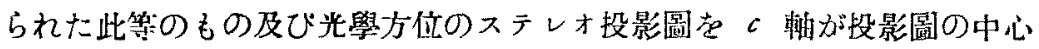
になる樣に轉換すれば，第壹圖の樣になる。同圖中黑點结純粹なアルバイ 
トの $\mathrm{X}, \mathrm{Y}$ 及び $\mathrm{Z}$ 軸の位置で小圓はこの長石について測定せられた $\mathrm{X}, \mathrm{X}$ 及び Z 軸の位置である。此の圖で見れば，此の長石の光學方位は（Oro） 面について對椅であるとは云ひ難い，即ち單斜晶系のものとは云ひ得ない 樣である。

上の晶系を定める䉆めの比較考察法は, 既に述べた樣に 決定的なもので はないので，更に一つの驗めしとして，第营圖の樣に定められた光學位に ついて，その消光位を圖式的に求め，之を竹內理學士の實測した消光角

第同表

\begin{tabular}{|c|c|c|c|}
\hline No. & 溥片方向 & 竹内(䆩測) & 渡邊(圆上) \\
\hline 1 & $\not(010)$ & $18^{3}$ & $13^{2}$ \\
\hline $\begin{array}{l}2 \\
3 \\
4\end{array}$ & $\not /(001)$ & $\begin{array}{l}2.5^{\circ} \\
4^{\circ} \\
3^{2}\end{array}$ & $\begin{array}{l}4.5^{3} \\
3^{\circ} \\
3.5^{3}\end{array}$ \\
\hline
\end{tabular}

比較すると，第寘表の樣になり，ほぶ一致するものと云ひ得る。即ち薄片 の方向及び推定せられた隻晶軸の力向は恬が正しいものであらうと想像せ られ，從つてこのものの光學方位が（OIO）面について 對稱的でないと云 ふ絬果も亦正しいのではあるまいか。

擱筆に當り貴重な標本を貸與せられ，且つ御愁切な御指導を賜つた䍇津 先生に媣く感謝の意范表する。

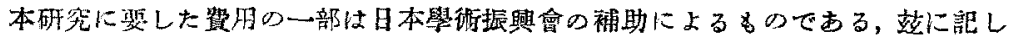
て同會に謝態を袁する。 